\title{
URBAN CORRIDOR AS A PUBLIC SPACE CASE STUDY : CORRIDOR PANTAI LOSARI STREET MAKASSAR CITY
}

\section{Sriany Ersina*1 \\ Department of Architecture, UIN Alauddin Makassar, South Sulawesi, IndonesiaV e-mail: *1sriany.ersina@uin-alauddin.ac.id}

\begin{abstract}
Abstrak_ An ideal public space should be a common ground, open and accessible for all including for people with disabilities. However in fact, along the beach Losari in Makassar City have inaccessible public space. Ideally, the various people who use and do interaction in the public space should be accommodated in the space. The Potential for conflict exist whenever and wherever people contact. Conflict is natural, normal and inevitable whenever people interact together. The disagreement and the difference on values conflict can be indicated by the unavoidable situation in human relationship. Therefore, defining the difference and strategy to manage the conflict in public space will be the focus of the paper. A Synergy, compromise, accommodative action and using a power are among others of the strategy to manage conflict to create a built environment towards an open and accessible public place. A Public space is the common ground where people carry out the functional and ritual activities that bind a community, whether in the normal routines of daily life or in periodic festivities. Urban Corridors that deals with mostly public space should serve the public at large, the plural society and the variety of human behavior.
\end{abstract}

Keywords : Public Space; Conflict in Public Place; Urban Corridor.

${ }^{1}$ Department of Architecture, The Urban Design Lab. The State Islamic University of Alauddin Makassar, South Sulawesi, Indonesia 


\section{INTRODUCTION}

Urban corridor is a public space is the common ground where people carry out the functional and ritual activities that bind a community, whether in the normal routines of daily life or in periodic festivities.

Urban design, that deals with mostly public space should serve the public at large, the plural society (Shirvani 1985) and the variety of human behavior (Kornblum 1979) It is crucial for our purpose that the future environment be an open one which the individual can easly penetrate, and in which he can act by his own choice (Banerjee 1990) In principle, the creation of the public space in corridor should consider its character as a common ground for various people activities, open environment with freedom to use, and accessible for all including for people with disabilities. The freedom to use the public space indicates the existence of at least, "Unwritten regulation" which relies on tolerating attitudes, behaviours and needs for others. No domination of an individual or a group over the others. There should be a fairness to utlitize the public space.

The change of the ownership of the public domain : Although (Dumouchel 1975) defined that land owned by government is public domain, people nowadays can find that the private owned land is also open and accessible for the public. The shifthing is occurred when the authority over the land has convinced the private owner for the success of the land control if the land is publicly used.

The change of the space enclosure : till the nineteenth century few buildings were public. Truly public space were nearly always out of doors. Public buildings (Hertsberger 1991) There is a shift on the character of space enclosure such public building. It is from open space to building space. The perception change of the private land owner to serve the public at the large makes more public buildings constructed. Department stores and various museums owned by private are among the public building's examples.

The change of the space character : traditional squares were closely identified with a purpose such as displaying political power or serving as a place for commerce. Nowadays many squares often have to specific purpose other than to provide charm or a pleseant meeting place. (Asensio Cerver 1997) There is an indication of shifting from more to show a political power (traditional and monumental character), or from more to accommodate traditional people needs (such organic character of the traditional market) to the more modern and dynamic in purpose. The tendency of urban area to build many super malls with attractive and recreational atriums show one of evidences of the change of the space character in corridor.

A Public space is the common ground where people carry out the functional and ritual activities that bind a community, whether in the normal routines of daily life or in periodic festivities (Krik R 1989) Urban Corridors that deals with mostly public space should serve the public at large, the plural society and the variety of human behavior.

\section{METHOD}

Research methodology can be seen as the techniques used to collected and analyze data. The data collected have to be related to the objective and problem statement. There are two types of methods that used in this study to obtain the relevant data which are literature review, and visual inspection. 


\section{A. Studies on Road Corridors Losari Beach, Makassar City}

Conflict is natural, normal, and inevitable whenever people interact together (Lingren 1996). Conflict is natural disagrrement resulting from individuals or groups that differ in needs, perceptions, feelings, emotions, attitudes, values, beliefs, or powers (Hoban 2004). Conflict in the public space on road corridor Losari Beach, Makassar City arise:

1. When one or a group ignore others needs.

Cities are now mostly inaccessible. Many cities have been designed and planned by what so called "a normal, young-adult, and relatively rich" architects urban designer and planners. They forget that city lived by various people, they subjectively think only essential for their need. As a result, city is rarcly or never friendly to children, people with disabilities, low income people, women's need.

2. When people interpret reality differently.

People may have different perception or perspective to see an urban problem. From the pedestrian user's perspective such us wheel chairs users, blind persons, families, children and tourist, the uncontrolled and crowding peddlers or known as kaki lima are really disturbing their walk passing through the pedestrian. From the peddler perspective, pedestrian is the public place where all people have a right to use including for people business. From the authority perspective, there is no legal aspect that regulates the informal sector such kaki lima do trading in the public space.

3. When people ignore their own or other's feeling and emotions.

The graffiti as a youth expression tool and media can make either people happy or angry. People will be happy to have a participative mural work which makes their neighbor more unique and beautifull. In the reverse, they will be angry when they find their lovely fences, doors, and walls being wildly painted.

4. When one party refuses to accept the fact that the other party holds something as a value.

Ideally, we conserve old things, not for their own sake nor in a quixotic attempt to stop change, but the better to convey a sense of history. This then implies a celebration of change and of the conflicts of values that accompany history. It means connecting the process of the past to present change and values, instead of attempting to detach it from them (Lynch 1992). Conflicts in conservation of an old district arise when a group insists to preserve the historical value of the area without understanding to need of present users and future generation. Why do we want to preserve? Because these aspects are part of our heritage? To improve the environment of the inhabitants? To earn money from tourism? On the other hand, investors demolish many old buildings for the sake of the modernization by considering the land value and inefficiency of the old building utilization.

5. When people use power as an important influence making others change their actions.

The lack of effective leadership or decision making or a lack of agreement about "who's in charge" or "how we are going to get things done" in any situation can be a source of conflict. In this leadership crisis, the use of a public open space could be dominated by individual or group and push aside other individuals/group who also have a right to use. Meanwhile, the authority from the government sometimes suspect negative things, suspicious and defensives to community activities on the public place. The authority often shows their power to control a public place by constructing fences around so that people do not have freedom to use the place. 


\section{B. Visual Inspection}

Visual inspection was undertaken along the beach Losari in Makassar City. The visual inspections were carried out without using any instrument, but photons have been taken for the purpose of given a strong evident to support the results of study.

\section{RESULTS AND DISCUSSION}

The data collected from the visual inspection will be analyzed and discussed.

\section{A. Visual Inspection}

1. Corridor View Condition

Throughout visual inspection,pedestrian ways and street along the beach Losari in Makassar City were used by the informal sector such kaki lima do trading in the public space..

\section{B. Analysis of Managing Conflict in Public Place}

The conflict is not always negative. The disagreement the difference or the above values conflict can be indicated by the unavoidable situation in human relationship (Lingren 1996) In Fact, it can be healthy when effectively managed. Healthy conflict can lead to growth and innovation, to new ways of thingking and to additional management option. If the conflict is understood, it can be effectively managed by reaching a consensus that meets both the individual's and society's needs. This results in mutual benefits and strengthens the relationship (Hoban 2004).

According to (Lingren 1996), there are five broad strategies people usually use in dealing with disagreement and conflict power, compromise, withdraw-avoid, placate-yield, and synergy. Similarly (Hoban 2004), categorized the conflict management strategies into collaboration, compromise, competition, accommodation, and avoidance. In some cases it may be necessary to have neutral facilitator to help move the conflicted groups/individuals toward consensus. Based on (Lingren 1996) and (Hoban 2004) strategies, it can be drawn a diagram as follows :

The win-win solution - I Win, You Win, is a synergistic approach attached to both the goals of the parties in conflict. Both are enthusiastically cooperate to reach consensus. Compromise "I win (a little), You win (a little)", is a negotiated resolution as a means for making the solution more tolerable to each party. As the users of public space have various activities, goals, and attitudes, they have to tolerate the interest for other parties, and attempt to serve the "common good".

As accommodative approach with making the situation on "I lose, You win" is effective ways of self protection and protecting your relationships with others. This strategy is generally used either when the issue is more important to others, or one tries to avoid conflict to other's need. "I win, You lose" strategy is resulted from a high concern of group own interests with less concern for others. The strategy involves resolution through using power and winning br force or coercion. It is generally used when basic rights are at risk.

Meanwhile an approach to reach a hopelessness strategy "I lose, You lose" shows efforts to protect the parties in conflict from being caught up in endless struggles that cannot be won. This avoidance approach is used when confrontation has a high potential for damage.

The concept of Universal Design maybe one of the best synergistic approaches to rich the win-win solutions. The concept of Universal Design is developed to address the 
specific needs of the disable at the same time that is a good solution for all other users (Cooper M 1998) When we design a park's gate with the ramp's width of wheel chair's users, it is most likely that other users are able to enter the park as well.

A street, including pedestrian is conceptually defined as "a place for movement as well as a place for exchange and for public contact" (Rapoport 1987). The ideal type of pedestrian should accommodate both the function of moving and of sharing. Pedestrian should be a place where all travelers including ones with disabilities could pass through easly, but in the same time it also gives them possibilities to do interaction socially (by stop and do chatting with friend, acting to make public space become liveable and pleasant) to do exchange economically (such allowing street vendor and street musicians to serve passing people), to do campaign and promoting a group concept or ideology to public. This ideal type of pedestrian allows all user to have a freedom to use the public space. They are all the winners.

If a walker used a car street instead of using pedestrian which is fully occupied by kaki lima, then the walker either does accommodative action to kaki lima or she/he actually tries to avoid the conflict. It sometimes also happened when a street cannot be used by any mode of transportation because it is crammed by demonstrators who protest a policy of the government. In this case, we understood that "people power" forces the street for operating only one function i.e. as the place for exchange political ideology. We can also find that a street is fully filled by visitors in the bazar's day of the district create a place for instant trading (economic exchange place) by permission of the local authority. The local authority can be one of the effective powers to manage the conflict in using public space.

\section{CONCLUSION}

There should be steps to manage the conflict in corridor Losari Beach street as a Public Place. We should start to analyze the conflict by understanding what the differ needs, values, perception, of involved parties which caused the conflict in using or creating the open and accessible public space. Then we determine the management strategy by carefully developing a synergetic approach, compromise, accommodative action, using power approach or leaving the conflict unsolved. When developing criteria for selecting or combining possible alternatives, we have to revisit the conflicting interest. It should also keep in mind principles such us fairness, and efficiency. The selected approach should be negotiated to all parties in conflict before its implementation. Whether through a pilot project or total development. The goal to be achieved remains the some towards more democratic, open and accessible public place. 


\section{REFERENCES}

Asensio Cerver, Fransisco. 1997. Redesigning City Square and Plazas. New York: Herats Book International.

Banerjee, Tridib and Michael Southworth. 1990. City Sense and City Design. Cambridge: The MIT Press.

Cooper M, Clare and Carolyn Francis. 1998. People Places. Design Guidelines for Urban Open Space. 2nd Edition. New York: Van Nostrand Reinhold Company.

Dumouchel, J Robert. 1975. Dictionary of Development Terminology. New York: McGraw-Hill Book Company.

Hertsberger, Herman. 1991. Lesson for Students In Architecture. Rotterdam: Uitgeverij 010 Publishers.

Hoban, Thomas J. 2004. Managing Conflict. A Guide for Watershed Partnerships.

Kornblum, William. 1979. The Psychology of City Shape.In Urban Open Space. New York: Rizzoly International Publication.

Krik R, Bishop. 1989. Designing Urban Corridors. Washington, DC: American Planning Association.

Lingren, Herbert G. 1996. Managing Conflict Successfully.

Lynch, Kevin. 1992. Good City Form. Cambridge: MIT Press.

Rapoport, Amos. 1987. Pedestrian Street Use: Culture and Perception., In Public Streets for Public Use. New York: Van Nostrand Reinhold Company.

Shirvani, Hamid. 1985. The Urban Design Process. New York: Van Nostrand Reinhold Company. 